\title{
THE DISTRIBUTION OF FE" ${ }^{\circ}$ TAGGED HUMAN ERYTHROCYTES IN CENTRIFUGED SPECIMENS AS A FUNCTION OF CELL AGE
}

\author{
BY E. RAYMOND BORUN, WILLIAM G. FIGUEROA, AND SEYMOUR M. PERRY
}

\author{
(From the Veterans Administration Center and the Department of Medicine, University of \\ California Medical Center, Los Angeles, Calif.)
}

(Submitted for publication October 22, 1956; accepted January 10, 1957)

This study demonstrates that the density of human erythrocytes increases with age and that cell populations with different mean ages can be isolated on the basis of this density gradient. The data suggest that the concentration of $\mathrm{Fe}^{59}$ in the bottom layer of centrifuged erythrocyte specimens may be used to estimate the mean life span of ageing cells.

\section{METHODS}

Six to ten microcuries of $\mathrm{Fe}^{\mathrm{s0}}$ were administered intravenously to eight hematologically normal subjects who had various chronic diseases (Table I). Five of the subjects received $\mathrm{Fe}^{\mathrm{s0}}$ iron globulin complex ${ }^{1}$ and three received $\mathrm{Fe}^{\infty}$ ferrous citrate ${ }^{1}$ that had been incubated with the subject's plasma or whole blood before injection. Specific activity of both preparations was 0.5 to $1.5 \mathrm{mC}$. per mgm. at the time of administration. One subject (C.A.) ${ }^{2}$ also received $100 \mu \mathrm{C}$. of $\mathrm{Cr}^{\mathrm{ol}}$ (1).

Twenty ml. heparinized blood specimens were drawn at the intervals indicated in Figure 1 and centrifuged in 10-ml. plastic tubes for 40 minutes at 3,000 RPM (approximately 2,000 G.). The tubes were placed in an alcohol-dry ice freezing mixture for a few minutes and were then cut 1 to $2 \mathrm{~mm}$. below the plasma-erythrocyte interface. The bottom portions containing the frozen erythrocytes were cut into four equal sections. The radioactivity of thawed aliquots from each section was measured in a well-type scintillation counter with a T1activated $\mathrm{NaI}$ crystal and expressed as counts per second per ml. of erythrocytes. The $\mathrm{Fe}^{60}$ and $\mathrm{Cr}^{\mathrm{\sigma l}}$ activity in specimens from C.A. were measured separately by differential pulse height analysis (1). Correction for isotope decay was based on the radioactivity of standards which were prepared from the injected material and counted with each blood specimen. The standard error of the counting procedure was less than \pm 2 per cent for most specimens and less than \pm 4 per cent for the low activity specimens.

${ }^{1} \mathrm{Fe}^{50}$ iron "IV-7 globulin" complex and $\mathrm{Fe}^{50}$ ferrous citrate were obtained from Abbott Laboratories, Chicago, Illinois.

2 Subject C. A. and a patient with non-spherocytic hemolytic anemia were studied in co-operation with Dr. I. M. Weinstein. Data from this and other patients with hematological abnormalities will be reported separately.
The proportion of erythrocytes discarded with the plasma ( $8 \pm 2$ per cent) ${ }^{8}$ was calculated from the total hemoglobin in plasma and erythrocyte sections of fourteen specimens.

$\mathrm{Fe}^{\infty 0}$ activity in unseparated whole blood erythrocytes was determined in twenty specimens from five subjects by counting aliquots of whole blood and dividing by the aliquot volume and hematocrit.

\section{RESULTS}

$\mathrm{Fe}^{59}$ concentration was highest in the top layer and lowest in the bottom layer of erythrocyte specimens drawn during the first 15 days after administration of the isotope. The concentration decreased in the top layer and increased in the bottom layer of specimens drawn between the 15th and 90th days, and this trend reversed between the 90 th and 150th days (Figure 1). The extremes of individual variation are illustrated by subjects S.I. and R.I. The systematic nature of the changes

TABLE I

Clinical data

\begin{tabular}{|c|c|c|c|}
\hline Subject & Sex & Age & Clinical diagnosis \\
\hline C. A. & $\mathbf{F}$ & 54 & $\begin{array}{l}\text { Hypertensive cardiovascular } \\
\text { disease. Cerebral vascular } \\
\text { accident. }\end{array}$ \\
\hline C. E. & $\mathbf{M}$ & 66 & $\begin{array}{l}\text { Hypertensive cardiovascular } \\
\text { disease. Cerebral arterio- } \\
\text { sclerosis. }\end{array}$ \\
\hline S. I. & $\mathbf{M}$ & 64 & $\begin{array}{l}\text { Stasis dermatitis. Arterio- } \\
\text { sclerotic heart disease. }\end{array}$ \\
\hline A. $\mathbf{R}$. & $\mathbf{M}$ & 56 & $\begin{array}{l}\text { Arteriosclerotic heart disease. } \\
\text { Osteoarthritis of the spine. }\end{array}$ \\
\hline $\begin{array}{l}\text { G. E. } \\
\text { B. U. }\end{array}$ & $\begin{array}{l}\mathbf{M} \\
\mathbf{M}\end{array}$ & $\begin{array}{l}62 \\
59\end{array}$ & $\begin{array}{l}\text { Rheumatic heart disease. } \\
\text { Hypertensive cardiovascular } \\
\text { disease. Arteriolar nephro- } \\
\text { sclerosis. Cerebral vascular } \\
\text { accident. }\end{array}$ \\
\hline R. I. & $\mathbf{M}$ & 58 & $\begin{array}{l}\text { Peripheral neuritis. Cerebellar } \\
\text { degeneration. Duodenal } \\
\text { ulcer. }\end{array}$ \\
\hline O. C. & $\mathbf{M}$ & 58 & $\begin{array}{l}\text { Hypertensive cardiovascular } \\
\text { disease. Cerebral vascular } \\
\text { accident. }\end{array}$ \\
\hline
\end{tabular}

3 Data reported in this manner represent the mean and standard deviation. 

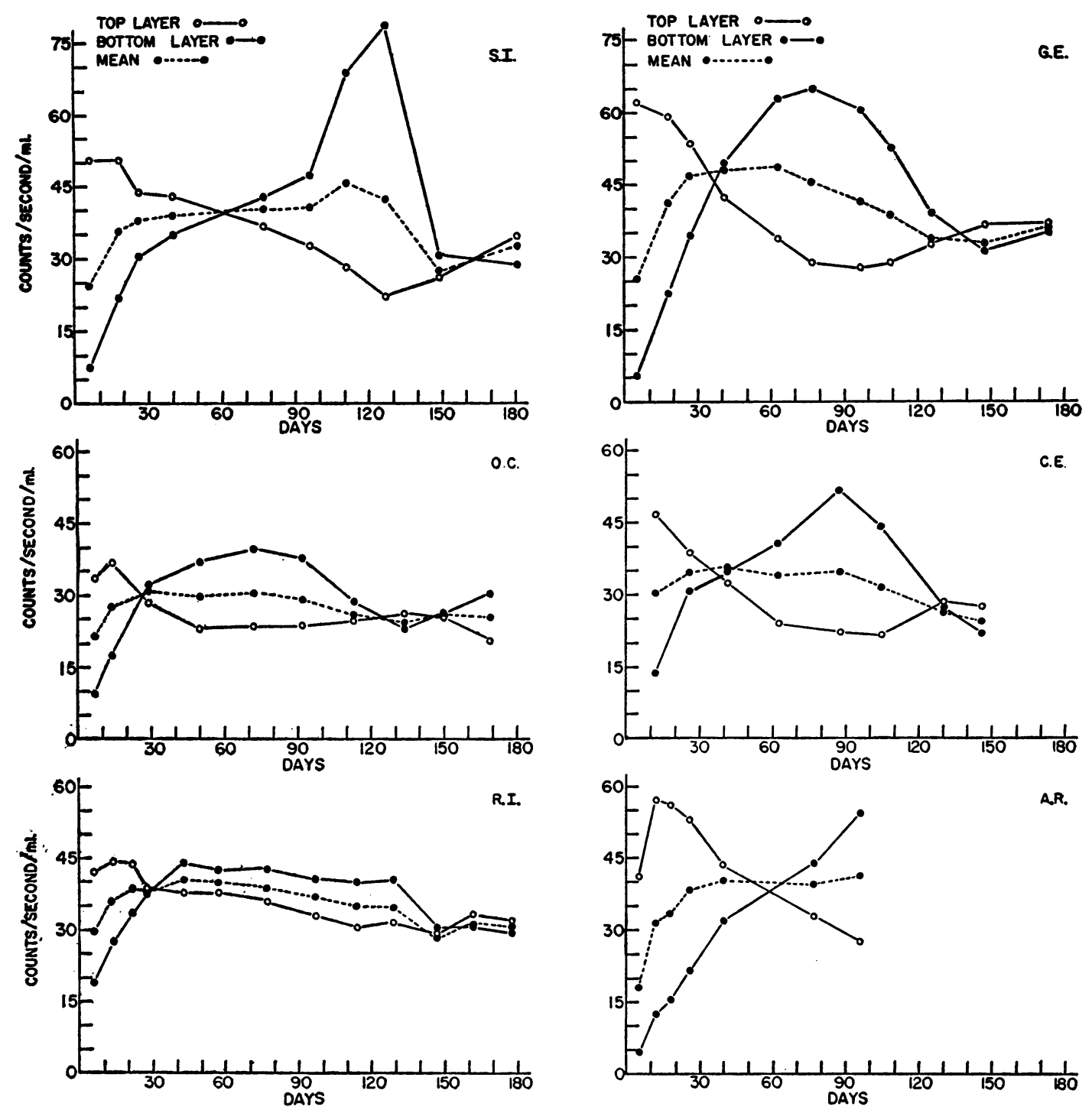

Fig. 1. The Fe" Concentration in the Top and Bottom Layers of Erythrocytes from Centrifuged Blood Spectmens Plotted Against Tmer in Days After Administration of the Isotope

The mean $\mathrm{Fe}^{\mathrm{m}}$ concentration in the four layers of erythrocytes is also plotted against time.

in isotope distribution with time is demonstrated in the logarithmic graph of the ratio

$$
\frac{\text { Top layer } \mathrm{Fe}^{58}}{\text { Bottom layer } \mathrm{Fe}^{68}}
$$

(Figure 2). This ratio decreased progressively during the first 80 to 130 days and then increased to a second maximum slightly greater than unity after 130 days.

In almost all specimens the $\mathrm{Fe}^{59}$ concentration in the middle layers was intermediate between that in the top and bottom. However, the concentration was slightly higher in the middle layer than in either the top or bottom of specimens from three subjects drawn between the 40th and 55th days, when the ratio $\frac{\text { Top layer } \mathrm{Fe}^{59}}{\text { Bottom layer } \mathrm{Fe}^{59}}$ was near unity.

The mean $\mathrm{Fe}^{58}$ concentration in the separated erythrocyte layers approximated the concentration in the unseparated whole blood erythrocytes of the same specimens, except in the initial specimens 


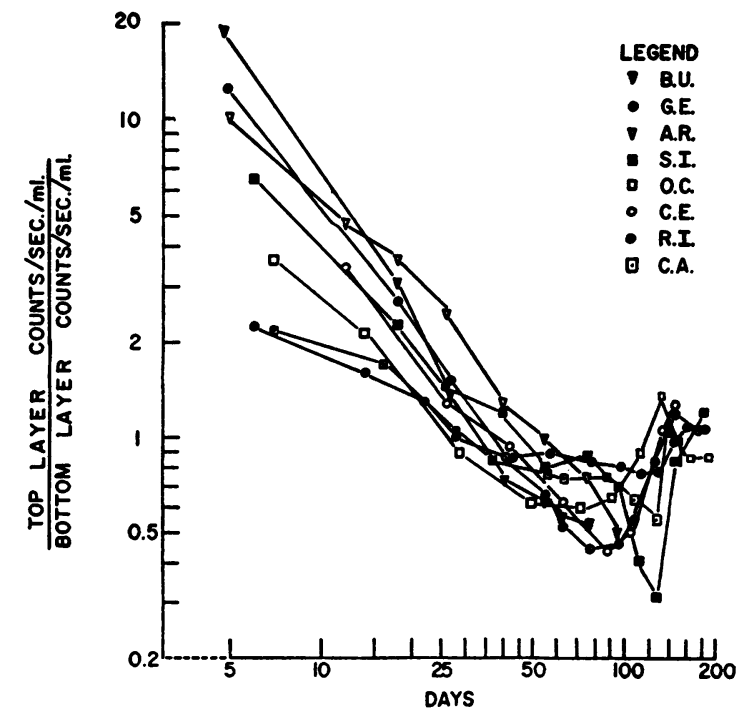

Fig. 2. Logarithmic Graph of the Ratio

$$
\frac{\text { TOP LAYER FE }}{\text { BOTTOM LAYER FE }}
$$

Plotted Against Time in Days After Administration of the Isotope to EIght SUbjects

where a significant proportion of the isotope was in cells discarded with the plasma. The ratio between mean concentration in erythrocyte layers and concentration in unseparated whole blood erythrocytes was $0.82 \pm 0.06$ in five of the initial specimens and was $1.00 \pm 0.06$ in ten specimens drawn between the 20 th and 41 st days.

The mid-point of the isotope appearance curve was 4 to 6 days when calculated by extrapolation from the mean $\mathrm{Fe}^{59}$ concentration in the separated layers, and was 4 days when calculated from the concentration in whole blood specimens of five subjects.

\section{DISCUSSION}

Previous investigators have shown that $\mathrm{Fe}^{58}$ incorporation is limited to immature cells of the erythrocyte series $(2,3)$ and that $\mathrm{Fe}^{58}$ tagged cells which appear in the circulation during the first five days after administration of the isotope to humans or rats have a relatively low density (4-6). Since there is probably no significant iron exchange in mature erythrocytes $(7,8)$, the change in relative density of $\mathrm{Fe}^{59}$ tagged cells may be followed throughout their life span.
This study confirms the fact that $\mathrm{Fe}^{59}$ tagged cells have a relatively low density when they first appear in the circulation. The increasing proportion of $\mathrm{Fe}^{59}$ in the bottom layer of centrifuged specimens drawn during the second half of their expected life span $(9,10)$ suggests that their relative density increases progressively with age but there is considerable individual variation in the magnitude of this change. ${ }^{4}$ Several investigators have utilized the relatively low density of reticulocytes to obtain concentrated specimens of these young cells (11-15). The present data indicate that the density gradient can be used to separate populations of mature cells with different mean ages from single specimens of normal human erythrocytes.

The decrease in $\mathrm{Fe}^{59}$ concentration in the bottom layer of specimens drawn 90 to 150 days after administration of the isotope is consistent with the expected time for the disappearance of senescent cells $(9,10)$. Since this decrease is followed by a period of relatively slight change when $\mathrm{Fe}^{59}$ concentration in the bottom layer is similar to that in the top layer, the mid-point of this decrease may be used to estimate the mean survival time (5) of tagged cells in the bottom layer. As the survival time of senescent cells is equivalent to potential life span (10), and senescent tagged cells are apparently concentrated in the bottom layer, an estimate of mean survival time of the cells in this layer may be considered an approximation of mean potential life span. The mean "potential" life span thus calculated from the mid-point of the original isotope appearance curve to the mid-point of the decrease in isotope concentration in the bottom layer was 103,119 , and 134 days, respectively, in subjects O.C., G.E., and S.I. One patient with non-spherocytic hemolytic anemia had a shortened "potential" life span of 52 days as well as a shortened $\mathrm{Cr}^{51}$ half-life survival time of 16 days. $^{2}$

\footnotetext{
4 Individual variations may be related to the magnitude of the gradient in density between cell populations of different ages or to other physical factors influencing their relative separability by centrifugation. Data from unpublished experiments demonstrate that the difference in density between the top and bottom layers of erythrocytes separated by this method is $8.3 \pm 6.2 \mathrm{gm}$. per $\mathrm{L}$. (S.E. $0.92 \mathrm{gm}$. per L.; p $<0.001$ ). Density was calculated from the weight of known volumes corrected for measured trapped plasma.
} 


\section{SUMMARY}

1. The distribution of $\mathrm{Fe}^{59}$ in the top, middle, and bottom layers of centrifuged erythrocyte specimens was determined at intervals after intravenous administration of the isotope to eight hematologically normal subjects.

2. The $\mathrm{Fe}^{59}$ concentration was highest initially in the top layer, increased in the bottom layer between the 15th and 90th day after administration of the isotope, and then decreased in the bottom layer after the 90th day.

3. The data indicate that the top, middle, and bottom layers of centrifuged erythrocytes have young, intermediate, and old mean cell ages, respectively.

4. A simple method was suggested for estimating the mean life span of ageing erythrocytes from the changes in $\mathrm{Fe}^{59}$ distribution.

\section{Addendum}

The mean "potential" erythrocyte life span, calculated as described above, was 115,115 , and 120 days, respectively, in subjects C.A., C.E., and a previously unreported hematologically normal subject. The mean value for six hematologically normal subjects is $118 \pm 10$ days.

\section{ACKNOWLEDGMENTS}

The authors gratefully acknowledge the interest and encouragement of Dr. Joseph F. Ross, and the co-operation of the Radioisotope Section of the Veterans Administration Center.

\section{REFERENCES}

1. Weinstein, I. M., and Beutler, E., The use of $\mathrm{Cr}^{51}$ and $\mathrm{Fe}^{\mathrm{so}}$ in a combined procedure to study erythrocyte production and destruction in normal human subjects and in patients with hemolytic or aplastic anemia. J. Lab. \& Clin. Med., 1955, 45, 616.

2. Walsh, R. J., Thomas, E. D., Chow, S. K., Fluharty, R. G., and Finch, C. A., Iron metabolism. Heme synthesis in vitro by immature erythrocytes. Science, 1949, 110, 396.

3. Lajtha, L. G., and Suit, H. D., Uptake of radioactive iron $\left({ }^{50} \mathrm{Fe}\right)$ by nucleated red cells. Brit. J. Haemat., 1955, 1, 55.

4. Ferrebee, J. W., Gibson, J. G., and Peacock, W. C., Studies on malarial parasites. IV. Some observations regarding the age of the erythrocyte invaded by plasmodium vivax. J. Infect. Dis., 1946, 78, 180.

5. Finch, C. A., Wolff, J. A., Rath, C. E., and Fluharty, R. G., Iron metabolism. Erythrocyte iron turnover. J. Lab. \& Clin. Med., 1949, 34, 1480.

6. Dreyfus, J. C., Schapira, G., and Kruh, J., Fractionnement des hématies selon leur âge. Centrifugation d'hématies marquées par le fer radioactif. Compt. rend. Soc. de biol., 1950, 144, 792.

7. Hahn, P. F., Bale, W. F., Ross, J. F., Hettig, R. A., and Whipple, G. H., Radio-iron in plasma does not exchange with hemoglobin iron in red cells. Science, 1940, 92, 131.

8. Gibson, J. G., 2nd, Weiss, S., Evans, R. D., Peacock, W. C., Irvine, J. W., Jr., Good, W. M., and Kip, A. F., The measurement of the circulating red cell volume by means of two radioactive isotopes of iron. J. Clin. Invest., 1946, 25, 616.

9. London, I. M., Shemin, D., West, R., and Rittenberg, D., Heme synthesis and red blood cell dynamics in normal humans and in subjects with polycythemia vera, sickle-cell anemia, and pernicious anemia. J. Biol. Chem., 1949, 179, 463.

10. Eadie, G. S., and Brown, I. W., Jr., Analytical Review. Red blood cell survival studies. Blood, 1953, 8, 1110.

11. Watson, C. J., and Clarke, W. O., The occurrence of protoporphyrin in the reticulocytes. Proc. Soc. Exper. Biol. \& Med., 1937, 36, 65.

12. Stephens, J. G., Surface and fragility differences between mature and immature red cells. J. Physiol., 1940, 99, 30.

13. Pritchard, J. A., Erythrocyte age and cholinesterase activity. Am. J. Physiol., 1949, 158, 72.

14. Allison, A. C., and Burn, G. P., Enzyme activity as a function of age in the human erythrocyte. Brit. J. Haemat., 1955, 1, 291.

15. Chalfin, D., Differences between young and mature rabbit erythrocytes. J. Cell. \& Comp. Physiol., 1956, 47, 215. 